\title{
Od przekładu intersemiotycznego do produktów typu tie-in, czyli transmedialny storytelling jako strategia tłumaczenia
}

\author{
Inez Okulska
}

Przekład intersemiotyczny, obok intra- oraz interlingwalnego stanowił jeden z trzech typów przekładu wyróżnionych przez Romana Jakobsona w słynnym artykule Językowe aspekty tłumaczenia, i obejmować miał taką sytuację translatorską, w której następował transfer pomiędzy odmiennymi systemami semiotycznymi - językiem naturalnym a maszynowym, tekstem literackim a obrazem, obrazem a dźwiękiem itp. Rozwój nowych technologii, prawa autorskiego (redefiniującego m.in. pojęcia autorstwa, oryginału czy licencji) oraz strategii marketingowych dotyczących produktu i sprzedaży sprawiają jednak, że pojęcie przekładu intersemiotycznego wymyka się swojej pierwotnej definicji, bez wątpienia jednak zjawisko przez nie opisywane nie przestaje intrygować badaczy, również w szerszym niż tylko translatologicznym kontekście. Mnie również. Zamierzam przyjrzeć się sytuacjom translatorskim, w których punkcie wyjścia znajdował się interlingwalny przekład literacki, ale nie stanowił on wyłącznie końcowego produktu, lecz także bodziec do powstania transmedialnych derywatów, które wspólnie tworzą transmedialną translatorską serię. Edward Balcerzan rozumiał tę ostatnią jako serię przekładów literackich tego samego utworu oferowanych przez różnych tłumaczy, ja proponuję to pojęcie rozszerzyć na serię przekładów, które na przestrzeni różnych mediów interpretują oryginał lub które pozostają w relacji zależności wobec samych siebie, tworząc wzajemny ciąg inspiracji. Jaką funkcję może w takiej serii pełnić przekład intersemiotyczny? W poszukiwaniu odpowiedzi pukam do sąsiada, bo jak wiadomo ekonomia humanistyce raczej po sąsiedzku, i zamiast z cukrem czy mąką wychodzę z transmedialnym storytellingiem i produktami tie-in. 
Tradycyjna hierarchia i temporalny porządek sugerujące, że dzieła literackie są adaptowane do medium filmowego zostały zaburzone przez novelization [beletryzacja], ideę chętnie wykorzystywaną przez producentów w celu zwiększenia emocjonalnego związku odbiorcy z oferowanym produktem - jeśli urzekła nas historia na wielkim ekranie, możemy otrzymać także jej wersję literacką (aż prosi się, by wziąć ten epitet w cudzysłów ze względu na nierzadko wątpliwe artystyczne walory takiego intersemiotycznego przedsięwzięcia), czyli książkową adaptację filmu. Taki sprzedażowy dodatek pełni funkcję zarówno pragmatyczną - bryku (bez konieczności przesuwania suwaka po osi czasu filmu możemy znaleźć informacje na temat przebiegu akcji, imion bohaterów itp.) czy źródła cytatów z ulubionych dialogów, jak i emocjonalną, pozwalającą zbudować i umocnić więź odbiorcy (transmedialnego, który jest np. zarówno widzem, jak i czytelnikiem) z wyjściowym produktem. Tego typu oferta produktowa nie budzi większego zdziwienia, podobnie jak niezwykle rozbudowana oferta gadżetów towarzyszących inauguracji ważnych medialnych dzieł opartych na szeroko rozumianych narracjach (najczęściej dotyczy to filmu lub książki, ale może towarzyszyć również wydaniu komiksu, albumu muzycznego, otwarciu wystawy czy wprowadzeniu nowej agresywnej kampanii reklamowej, która staje się autonomicznym produktem w sensie narracyjnym - miarą będzie nie tyle medium, co potencjał identyfikacji marki).

Te towarzyszące produkty-dodatki noszą miano tie-in [powiązanych] i choć można nabyć je osobno ${ }^{1}$, ontologicznie pozostają w relacji hierarchicznej zależności, podobnie jak przekład względem oryginału czy epiteksty względem tekstu głównego. Produkty typu tie-in mogą być narracyjne lub nienarracyjne ${ }^{2}$. Nienarracyjne towary powiązane to między innymi praktyczne przedmioty (koszulki, torby, kubki z motywem), zabawne gadżety (np. podajnik wykałaczek w kształcie Lorda Vadera - wykałaczka automatycznie wysuwa się w miejscu miecza) czy „wzbudzające artefakty” [evocative artefacts], o których pisze Allison Thompson w kontekście fanów Jane Austin - lawendowe mydło czy pióro do pisania tworzące klimat odpowiadający wyobrażonej reprezentacji świata autorki i bohaterek jej powieści: „Jane z pewnością używała gęsiego pióra do napisania tej powieści, myśli sobie fanka, to ja też będę”3. Do najdziwniejszych produktów tie-in należą m.in. lód na patyku w kształcie Jamesa Bonda odgrywanego przez Daniela Craiga, trumny nawiązujące do stylistyki Star Treka, wibrująca miotła Harry’ego Pottera czy kawa sprzedawana w sieci marketów 7 Eleven pod egidą serialu Sherlock Holmes, która jednak nie nawiązywała do powiązanej marki za pomocą walorów smakowych, aromatu czy formy kubka, a wyłącznie dzięki obudowie tekstowej - na plakatach i przy stanowiskach pojawiały się gry i quizy („Ile masz w sobie Sherlocka?”) oraz pojęcia z pola semantycznego charakterystycznego dla tego superbohatera: „mystery”, „investigation”, „intrigue”.

\footnotetext{
${ }^{1}$ Pierwotne definicje strategii sprzedaży tie-in zakładały rzeczywistą relację zależności, czyli sprzedaż warunkową - zakup jednego produktu wymagał zakupu drugiego u tego samego producenta (m.in. M.L. Burstein, The Economics of Tie-in Sales', „The Review of Economics and Statistics” 1962, nr 42, s. 68), np. do drukarki EPSON miały pasować tylko tonery tej samej firmy. Dzisiaj jednak tie-in oznacza raczej licencję na autoryzowane produkty powiązane tematycznie z filmem, książką czy innym dziełem artystycznym. Mogę one wykorzystywać strategię transmedialnego storytellingu, a więc dostarczać narracyjnych wariacji lub formalnych wariacji na temat jej przedstawień lub po prostu nawiązywać do motywu, bohaterów, nazw czy stylistyki wyjściowego utworu, nie oferując żadnych dodatkowych narracji.

${ }^{2}$ Por. Hype. Bestsellers and Literary Culture, red. J. Helgason, S. Kärrholm, A. Steiner, Lund 2014, s. 28.

3 „Jane must have used a quill pen to write with, this fan thinks, so I will too”. A. Thompson, Trinkets and Treasures: Consuming Jane Austen, "Persuasions on-line" 2008, nr 28 (2), <http://www.jasna.org/persuasions/ on-line/vol28no2/thompson.htm> dostęp: 20.09.2016.

${ }^{4}$ K. Puchko, 12 Weird Movie Tie-In Products, „Mental Floss” z dnia 16.02.2015 <http://mentalfloss.com/uk/ weird/27406/12-weird-movie-tie-in-products> [dostęp 5.06.2016].
} 
Drugi typ powiązanych produktów-dodatków, narracyjny, bazuje na strategii transmedialnego storytellingu, który oznacza „zintegrowane doświadczenie na przestrzeni różnych mediów”. Uzyskanie takiego poszerzonego, ale koherentnego doświadczenia możliwe jest dzięki „transponowaniu narracji na różne platformy. Na przykład na jednej z nich może odgrywać się główna historia, na innych w centrum uwagi pojawiają się pojedyncze wątki czy postaci, ale ogólny nadrzędny motyw pozostanie wspólny”6.

W 2003 roku Henry Jenkins apelował, że „to, co nazywa się transmedialnym, multiplatformowym czy poszerzonym storytellingiem reprezentuje przyszłość świata rozrywki"7, ze względu między innymi na postępującą konwergencję mediów ${ }^{8}$, i rzeczywiście, dziś transmedialne dodatki towarzyszące premierze filmu, książki, serialu czy innych zjawisk kulturowych są naturalnym, a wręcz podstawowym i niezbędnym, elementem strategii produktu. Dlatego też, jak sugeruje Mittell, warto rozróżnić pomiędzy elementami paratekstowymi, które służą wyłącznie do promocji, wzbudzenia zainteresowania, wprowadzenia czy podjęcia dyskusji na temat tekstu głównego (strony internetowe, funpage, trailery, plakaty itp.), a tymi, które mają na celu rozbudowanie narracji i zawartego $\mathrm{w}$ niej świata ${ }^{9}$, a także poszerzenie pola zaangażowania i doświadczenia odbiorcy percypującego daną narrację.

Jeśli zgodnie z tymi założeniami odpowiednio szeroko potraktować definicję produktów-dodatków, towarzyszących w licencjonowany sposób premierze czy sprzedaży produktu głównego, to jako narracyjne tie-in można by określić takie elementy promocji, jak wieczór autorski zarówno z udziałem autora, jak i tłumacza (efemeryczny, ale jednak produkt) czy materiały wideo (jak np. w sytuacji przekładu tomu Wiedeński High Life Jakobe Mansztajna, któremu towarzyszył specjalnie z tej okazji nakręcony przez wydawnictwo OFF Press klip przedstawiający autora) oraz intersemiotyczne derywaty powstałe na bazie przekładu.

Mogą one mieć szczególne znaczenie przy wprowadzaniu na rynek przekładów z języków niszowych, dzieł autorów nieznanych rodzimemu odbiorcy lub szczególnie wymagających, z którymi należy wytworzyć związek emocjonalny oraz zadbać o rozpoznawalność.

Jeśli chodzi o te ostatnie, dobrym przykładem marketingowego działania noszącego znamiona transmedialnego storytellingu z wykorzystaniem przekładu intersemiotycznego wykazało się wydawnictwo Biuro Literackie. W latach 2007-2013 nakładem tej oficyny ukazywały się między innymi książki prozatorskie, poetyckie oraz antologie autorów ukraińskich w przekładzie na język polski. Wiersze pochodzące $\mathrm{z}$ tych wydań stały się następnie punktem wyjścia do konkursu ogłoszonego w 2014 roku „Komiks wierszem”, który przed uczestnikami stawiał zadanie przekładu wybranych (przełożonych już wcześniej interlingwalnie) wierszy na język medium komiksu, by później

\footnotetext{
${ }^{5}$ Cross-media storytelling 'refers to integrated experiences across multiple media' (Cross-Media Communications: An Introduction to the Art of Creating Integrated Media Experiences, red. D. Davidson, Pittsburgh 2010, s. 7).

${ }^{6}$ Transmedia storytelling conveys storylines over multiple platforms. For example, on one platform you can follow the main story, on another a minor character, but the overall theme remains the same. S. Kalogeras, Transmedia Storytelling and the New Era of Media Convergence in Higher Education, Hampshire 2014 - brak numeracji stron.

7 [W] hat is variously called transmedia, multiplatform, or enhanced storytelling represents the future of entertainment.

${ }^{8}$ H. Jenkins, Transmedia storytelling, „MIT Technology Review”, 1.01.2003, <https://www.technologyreview. $\mathrm{com} / \mathrm{s} / 401760 /$ transmedia-storytelling/ $\geq$ [dostęp 25.05.2016]

${ }_{9}$ J. Mittel, Complex TV: The Poetics of Contemporary Television Storytelling, New York 2015, s. 293.
} 
nagrodzone prace zebrać w almanachu Komiks wierszem po ukrainsku, który w księgarni wydawnictwa pojawił się w styczniu 2015 roku. W opiniach-blurbach towarzyszących tej pozycji można przeczytać, że „kiedy wokół wiersza zaczynają narastać nowe rzeczywistości (...) jest to powrotem ku wieloznaczności, czyli odkryciem za każdym zdaniem nowego i nowego dna" (Andrij Lubka) oraz że „pomysł połączenia komiksu z poezją jest doskonałym sposobem na wydobycie z cienia niedocenianej liryki” (Natalia Marcinkiewicz), zatem ów transmedialny derywat okazuje się dodatkiem niemal nieodzownym, bo komplementarnym, sensotwórczym, nobilitującym. Pozostaje z jednej strony w relacji zależności - również dlatego, że do poetyki komiksu należy słowo, bezpośrednio przeniesione $z$ oryginału (przełożonego) wiersza - jawnie podkreśla się jego przekładowy, derywacyjny charakter, z drugiej zaś owo powiązanie (w sensie tie-in) jest funkcją strategii produktu, który owego dodatku nie tylko potrzebuje, ale wręcz wymaga, by dopełnić swojej obecności na rynku.

Odmiennie sytuacja przedstawia się w przypadku klasyka literatury, dla którego funkcja dodatku stanie się szansą na komercyjne drugie życie i dotarcie do nieosiągniętej dotychczas grupy docelowej.

David Damrosh, szef [chair] Wydziału Komparatystyki Literackiej na Harvardzie, już parę lat temu podkreślał potencjał badawczy, jaki niesie za sobą poszerzenie pola o nowe media, w których pojawiają się inkarnacje motywów i bohaterów znanych z kanonu literatury światowej (world-literature, termin, którego autorem jest Damrosh). Chociaż w swojej refleksji Damrosch skupia się głównie na kwestiach geopoetyki i uniwersalności tzw. figur globalnych, archetypów i motywów, pochodzących lub spopularyzowanych przez klasyki literatury i reprodukowanych w innych mediach, opisując je z perspektywy zadań i możliwości komparatystyki, a nie przekładu, zaobserwowane przez niego przykłady są interesujące także dla niniejszych rozważań, bowiem wszystkie opisywane przypadki u swych źródeł miały przekład (zarówno literacki, jak i intersemiotyczny).

Najciekawszym z punktu widzenia opisywanych tu zjawisk wydaje się przypadek Piekła Dantego, także ze względu na jego anachroniczną recepcję. W 2010 roku amerykańska firma Electronic Arts wydała grę komputerową zwaną Dante's Inferno, stanowiącą bardzo luźny, ale jednak przekład poematu na język i wizualne możliwości medium gry. Sama tego typu adaptacja nie byłaby szczególnie spektakularna, bo gra w ramach dodatku tie-in jest popularnym produktem, omawianym i klasyfikowanym przez medioznawców:

Gry typu tie-in zazwyczaj obierają jedną z dwóch opcji narracyjnych, jeśli chodzi o sposób prezentacji wydarzeń wyjściowej powieści. Pierwsza z nich oznacza ponowne opowiedzenie akcji, które pozwala graczom uczestniczyć w ogólnym zarysie linii narracji - strategia te jest typowa dla gier powiązanych z filmami, jako że większość gier we franczyzie jak Władca pierścieni czy Toy Story nieco różnią się od oryginalnej historii (...) Dla telewizyjnych transmedialnych dodatków tie-in bardziej typowe jest potraktowanie gry jako nowego odcinka serialu, przedstawiającego wydarzenia, które mogłyby zaistnieć w telewizyjnym wydaniu, ale z jakichś przyczyn się w nim nie pojawiły ${ }^{10}$.

\footnotetext{
${ }^{10}$ Tamże, s. 302. Tie-in games typically follow the two options outlined for novels for what narrative events will be told. The first is to retell events from the source material, allowing players to participate in the original core narrative this strategy is common for film tie-ins, as most games from franchises such as The Lord of the Rings and Toy Story vary little from the original film's narrative events [...] More common to television tie-ins is treating the game as a new episode in the series, depicting events that could feasibly function as an episode from the series but have not.
} 
Tym, co wyróżnia tę grę spośród innych adaptacji, jest strategia sprzedaży, która zakładała zapowiedź produktu za pomocą specjalnego zestawu wydanego na trzy miesiące przed premierą gry. Zestaw ten, pomieszczony w pudełku, dla budowania identyfikacji marki, opatrzonym tą samą ilustracją na okładce, co później sama gra (półnagi Dante-wojownik w hełmie), oprócz kolorowej 16-stronnicowej wkładki ze screenami z gry prezentującymi wizualną interpretację klasyka literatury, wprowadzenia autorstwa „producenta wykonawczego" gry i akademickiej interpretacji dzieła, zawierał papierowe wydanie Piekła Dantego w przekładzie Henry'ego Wadswortha Longfellowa z 1867 roku. Sprzedażowym dodatkiem do transmedialnego derywatu, przypominającym te powstające na licencji tie-in, staje się zatem jego rzeczywisty „oryginał”, który sam jest tłumaczeniem, bowiem translatorski charakter inspiracji podkreślony jest zarówno poprzez ekspozycję nazwiska tłumacza na okładce, jak i blurb:

Rozpętało się prawdziwe piekło. Fascynująca gra Piekło Dantego wyprodukowana przez Electronic Arts z impetem podbiła rynek, a to jest książka, która oferuje niezwykły wgląd w powstanie tej gry. Pozwól, by Henry Wadsworth Longfellow za sprawą swojego wybitnego przekładu przeniósł cię do źródeł epickiego poematu Dantego. Zaprezentowany w całości - oto i on, inspiracja i fundament $\operatorname{gry}^{11}$.

Mimo tak bezpośrednich i jawnych odniesień do źródła, być może między innymi w wyniku rozpowszechniającej się strategii marketingowej polegającej na wspomnianej 'beletryzacji popularnych narracji, niektórzy użytkownicy z rezerwą lub niemal agresją („WTF is this shit?”12 odnosili się do owego źródłowego dodatku, traktując go raczej jako produkt będący ubocznym efektem strategii produktu samej gry, dopisany prequel, a nie autonomiczne dzieło literackie zasługujące na podwójną uwagę i estymę, bo stanowiące źródło bezpośredniej inspiracji, punkt wyjścia tej transmedialnej narracji. Podobny efekt odwróconej hierarchii przekładu i źródła może wywołać sprzedaż klasyków literatury w formie licencjonowanych edycji tie-in do hollywoodzkich ekranizacji (znów najczęściej opartych na literackim przekładzie obcojęzycznych pozycji światowego kanonu) - na okładce takiego wydania Anny Kareniny widnieje ambiwalentny raczej paratekst „Now a major motion picture / Starring Keira Knightley and Jude Law”. Układ typograficzny oraz obecność nazwisk aktorów i screenu z filmu mogą niewtajemniczonemu odbiorcy zasugerować, że Leo Tolstoy to reżyser lub ewentualnie producent filmu, a nie autor literackiego dzieła, które zostało poddane filmowej adaptacji. Suplement w postaci scenariusza dodatkowo może podważać integralność oryginału i znów podsunąć mylny wniosek, że owo powiązane wydanie jest efektem „beletryzacji”, fabularyzowanego naddatku nabudowanego na dołączonym scenopisie. O złudzeniu, jakoby Leo Tolstoy pisał po angielsku, nie wspominając:

\footnotetext{
${ }^{11}$ All hell is breaking loose. Electronic Arts' thrilling video game Dante's Inferno has exploded on the scene and this is the book that provides unique insight into its creation. Go back to the source with Henry Wadsworth Longfellow's celebrated translation of Dante's epic poem. Presented in its entirety, here is the foundation and inspiration for the game. D. Damrosch, Geopoetics: World Literature in the Global Mediascape, [w:] Figuren des Globalen. Weltbezug und Welterzeugung in Literatur, Kunst und Medien, red. Ch. Moser, L. Simonis, Göttingen 2014, s. 215.

${ }^{12}$ Tamże, s. 215-216.
} 


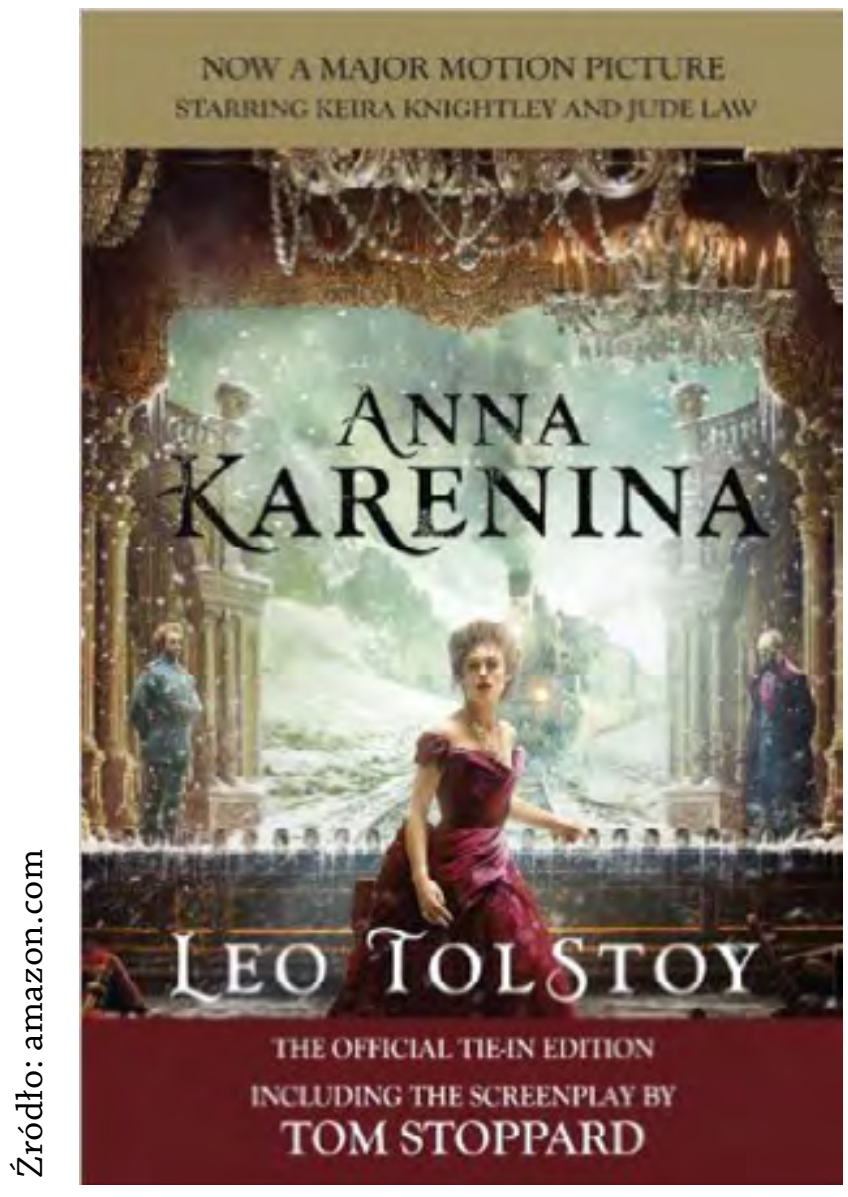

Powyższe przykłady odnoszą się do rzeczywistych strategii sprzedażowych inicjowanych przez wydawców. Ale metafora transmedialnego (transgatunkowego) storytellingu wydaje się operatywna także w przypadku opisu sytuacji bardziej nietypowych, w których to tłumacz staje się inicjatorem produkcji derywatów powiązanych $z$ oryginałem, $w$ tym także powstałych w wyniku przekładu intersemiotycznego.

Krzysztof Bartnicki po niemal dziesięciu latach pracy ukończył i opublikował pełen przekład Finnegans Wake Jamesa Joyce’a. Już sam przekład interlingwalny przy takim bogactwie języków w tekście źródłowym stanowi niezwykle szerokie pole badawcze dla translatologów, mnie jednak bardziej niż poetyka przekładu literackiego zajmować będzie jego potencjał twórczy dla transmedialnego storytellingu. Kilka miesięcy po premierze przekładu wydawnictwo Ha!art opublikowało książkę pod tajemniczym tytułem Fu wojny (2012), o której wydawca i autor w przedmowie twierdzili, że jest zbiorem przekładów starochińskich tekstów o strategiach translacji, opatrzonych przykładami z Finnegans Wake, utrzymanych w duchu przypowieści opartych na alegorii wojny i taktyki. Całość okazała się niezwykle finezyjną translatorską mistyfikacją, przygotowywaną we współpracy z sinologami (zawierała m.in. „oryginalne” frazy zapisane chińskimi literami), którą zdemaskować mogły między innymi nazbyt nowoczesne ujęcia problematyki translatorskiej ${ }^{13}$. Publikację tę można uznać za narracyjny, przekładowy i zarazem przekładoznawczy tie-in Finneganów Trenu, o charakterze spin-offu, który głównym bohaterem swojej narracji czyni poboczny wątek pozycji wyjściowej - sam proces przekładu. Zmienia się też medium (w tym wypadku gatunek tekstu) - zamiast przekładu dzieła literackiego otrzymujemy zmistyfikowany przekład literatury non-fiction. Jak się niebawem okazało, był to dopiero początek produkcji powiązanych transmedialnych dodatków typu tie-in oferowanych przez tłumacza, poszerzających horyzont doświadczenia produktu bazowego, czyli dzieła Joyce'a - w przekładzie na język polski lub oryginale. Rok później na rynku pojawiła się książka (aczkolwiek nakładem już innego wydawnictwa - Sowa, ale wydana na żądanie autora) zatytułowana Da capo al finne, stanowiąca przekład Finnegans Wake (co istotne - tym razem tłumacz znów sięga po anglojęzyczny oryginał) na kryptogram muzyczny. Tytuł książki, nawiązując do joyce'owskiego słowotwórstwa, współgra z muzycznym wyrażeniem

${ }^{13}$ I. Okulska, Przekład - wojna - koń trojański, [w:] Przekład - kolonizacja czy szansa?, red. P. Fasta, Seria „Studia o przekładzie", Katowice 2013, s. 93-104. 
„da capo al fine”, czyli od początku do końca. Dodatek w postaci jednej literki 'n' sprawia, że w wolnym przekładzie można rozumieć go jako „od początku do Finnegans Wake” czy „od A do F”, co z kolei można półżartem odnieść do translatorskiej i twórczej pracy Bartnickiego - gdziekolwiek zacznie i tak ostatecznie skończy na Finnegans Wake. Na ponad 130 stronach książki umieszczony został ciąg liter, niewielką czcionką, bez spacji, podziałów ani wyróżnień, który sam autor nazywa 'monoblokiem':

\begin{abstract}
eeeaedetheaheheheeegaggegadeaagecehegeeaBeet $t$ aaaggedaaetecdeab eehecadecgeaeade fheheaf caeadecaedeheAeadhebaf $\mathrm{fghgeeadehedeecee}$ edef heDeeaadhece fheeheeahhadeedhbbbegadheehacagheahade fheabedeh chcedf heeaadeeabehgheeahg fhef fbhaehagaeeheeegaheehadeeaeafehea aefef eheaheaeaadf feeadgeh $f$ heaehaadheecahaeggchechgacf feegeaeef faeheegfeabccefhbehdadeheeeef hecdabaeadeeeecefhebeaf ahadadeaf $f$ ahehaef aebeeaceecgedfededf aeaeeef ef heehacahacahaehabef hachchchg addheagefGCdeef abeheghgchabbadgaheebecaefedadaghheaaedgadbeeaad eag fhchagecahcheef hgbhaeaccbbeagheaeaghhaeedhaehechagefaedcceab haheeaddghahahedahbachecdddeef ha fhaaehea f aeadf ecahheheBhheBehh adedadaedhaf heaheeccaedececaheaedeeddbegedHeahaahaehehaechahgah eaheeachacefaaedcaceaheeabeaheeehebbeeecaeeaaggebegededdafeadaa df hehaehaefeadaceehgef adeeecebeehgadaghchghaehaebbachebadhheea aeecebefeefeedgadheHeaaehchaefdfgagaadhgceacedheaggaehbecaeagec aadfhghaebahadeahaheheef heghaf hhefheaebhedggdheadf fach f fhedFhec hagehcheacfaegehaagageaaef hedadegha fagadhhgeaf acef heheheahededa eeeaeahaeheaghaaccabeadeagagdeegchehgheaedhagecdeahegfafeeadhef eaefheDBaeaheadhebahdhchhedfeedhef headhCaaaghadheheGdaagedadafe heacaaBaccadf $f$ acedbeaheeaeedeeebeaefeaf aef $f$ aeaAdaadBeaeebhegace fgaeeaeheadeaegehdedaheeDecaeeehfef heecf feadhheheeebebacheachhe beaGabaechdadeaeghfghbghahaeebGeagdeHedhfaaheedheabeadheedhcaaa
\end{abstract}

Źródło: culture.pl

Ów tekst składa się wyłącznie z powtórzeń ośmiu liter w przeróżnych kombinacjach, ich kolejność jednak nie jest dowolna, lecz wynika z ich pierwotnej kolejności w tekście oryginału. Tak radykalną redukcję można by uznać za (ryzykowną) operację tekstową i podważyć jej intersemiotyczny charakter, gdyby nie fakt, że ocalone litery odpowiadają nutom, a cała książka jest partyturą przeznaczoną do realizacji. Co zresztą sam tłumacz udowadnia, zamieszczając własne audialne efekty lektury Da capo na portalu SoundCloud: <https://soundcloud.com/ gimcbart/ $\geq$, twierdząc, że w dziele Joyce'a zaklęte są między innymi hymny narodowe, melodie ludowe, ale także Marsz imperialny znany fanom Gwiezdnych wojen czy walc z Ojca chrzestnego. Choć tego typu przekład nie należy do najbardziej oczywistej poetyki transmedialnego storytellingu (ponieważ opowiada za pomocą liter generujących dźwięki), to z pewnością wypełnia jego podstawowe funkcje - przywiązania do produktu bazowego i rozszerzenia zakresu jego doświadczania, czego potwierdzeniem może być recenzja czytelnika (słuchacza?):

tekst Joyce’a zaczął brzmieć, szumieć różnorakimi dźwiękami. (...) Poczułem, jak schodzę do kategorii subiektywnego pre-tekstu, do archetypicznych wartości języka, zawartych w emitowanych dźwiękach, czyli akustycznych drgnieniach powietrza, odchodzących od sensu, zmierzającego do nieznanego odbiorcy meta-wymiaru. (...) Bartnicki zdekonstruował tekst Finnegans Wake poprzez dźwięk, dokonując jego ostatecznego demontażu i unieśmiertelnienia jednocześnie. Z tekstu niemożliwego uczynił tekst potencjalny, dowyobrażeniowy ${ }^{14}$.

\footnotetext{
${ }^{14}<$ http://lubimyczytac.pl/ksiazka/157361/da-capo-al-finne>.
} 
Powiązany dodatek wyprodukowany przez tłumacza okazuje się zatem nie tylko ofertą doświadczenia opcjonalnego, ale kluczem do percepcji Finnegans Wake, a jego obecność staje się warunkiem lektury produktu bazowego, wpisując go w ten sposób w pierwotne założenia strategii tie-in.

Pośród wielu definicji i klasyfikacji przekładu intersemiotycznego ta postulowana przez Teresę Tomaszkiewicz wydaje się idealnie wpisywać w zamysł tłumacza, bo - nieco ironicznie w tym kontekście - skupia się nie tyle na formalnych aspektach transferu, co na jego potrzebie:

Nadawca, stwierdzając pewien brak perfekcji rzeczywistej lub przypuszczanej w komunikacji za pomocą środków tylko językowych, wyraża pewien sens, stosując elementy kodu językowego, który zostaje zakodowany w inny sposób ${ }^{15}$.

To nieoczywiste ujęcie zakładające pragmatycznie, że przekład intersemiotyczny pojawia się tam, gdzie język zawodzi, wpisuje się w motywację Bartnickiego-tłumacza, ponieważ ten nie ukrywa, że choć Finnegans Wake go fascynuje, to „zawodzi jako literatura”. A potem dodaje:

Na panewce spalił Joyce’owy plan oddania głosu ludzkości. (...) Bez oporów można za to uznać skuteczność estetyczną dzieła, a co najmniej jego fragmentów. Kto nie rozumie $F W$ na poziomie leksyki, semantyki - jest w stanie cieszyć się melodyjnością nieznanego narzecza w recytacji, skutecznością rytmu, rymu, aliteracji, onomatopei, eufonii, bliską skuteczności pieśni, a ogólniej muzyki. Ale przecież w rywalizacji na wzruszenia melodyczne literatura w roli muzyki nie zdoła pokonać muzyki w roli własnej ${ }^{16}$.

Istotnym zadaniem transmedialnego storytellingu jest również zwiększenie stopnia interaktywności u odbiorcy poprzez prezentację bazowej narracji (lub jej derywatu w postaci spin-offu) za pomocą innych, multifunkcjonalnych form. W przypadku Da capo muzycznie sprawny czytelnik ma generować własne odczytania, interpretując pauzy, długości tonów itp. na swój sposób, dokładając kolejne ogniwa w tym łańcuchu produktów powiązanych. Łańcuch ten dobrze zresztą opisuje zapowiedź premiery remiksu (Finnegans Wake Remixed, co już zakrawa na mechanizm znany z fan-fiction, gdy utwór zaczyna żyć własnym życiem dzięki zaangażowaniu i inwencji odbiorców) w radiu Alternator: „joyce’a obrócono w finnegans wake. finnegans wake obrócono w literki. literki obrócono w nuty. nuty obrócono w midi. midi w miks. miks w radio. [słuchajcie, słuchajcie!]”"17.

W rozmowie po publikacji Da capo Bartnicki zachęcony pozytywnymi reakcjami (m.in. propozycją współpracy ze strony muzyków) powiedział: „sądzę, że to początek muzycznych eksperymentów na Joysie”. Z całą pewnością to nie koniec eksperymentów nie tylko muzycznych, ale transmedialnych, bo tę narrację o języku niemożliwym i totalnym, o niedocenionym genialnym pisarzu i poszerzaniu granic czytania, Bartnicki opowiada wciąż na nowo, oferując odbiorcom kolejne produkty z tej serii - skądinąd translatorskiej.

${ }^{15}$ T. Tomaszkiewicz, Przekład audiowizualny, Warszawa 2008, s. 73.

${ }^{16}$ K. Bartnicki, Przedmowa, [w:] tegoż, Da Capo al Finne, Warszawa 2015, s. 4.

${ }^{17} Z a$ : M. Gliński, Polak złamał kod Joyce’a, „culture.pl”, 27.01.2014, <http://culture.pl/pl/artykul/polak-zlamalkod-joycea> [dostęp: 4.06.2016]. 
Tym razem tłumacz, w duecie $\mathrm{z}$ grafikiem, przygotował książkę $\mathrm{w}$ formie rolodeksu, czyli kołowego wizytownika, który zawiera ponad 600 kart. Przekład na kod werbowizualny ${ }^{18}$ wymagał podobnie jak w przypadku muzycznej partytury pewnych redukcji i selekcji. Tym razem narracja jest silnie osobowa - nastawiona na bohaterów, bowiem z każdej strony $F W$ miały zostać postaci i wokół nich nabudowane wydarzenia, tak by można je było przedstawić właśnie w formie wizytówek. Numery telefonów czy adresy to oczywiście dalsza część szyfru utrzymana w duchu numerycznych zagadek kodowanych w tekście oryginału przez autora. Na kartach pojawiają się również oryginalne cytaty, ale jak podkreśla tłumacz, nie miały stać się one nadrzędnym elementem, lecz ustąpić miejsca interpretacjom wizualnym $^{19}$.

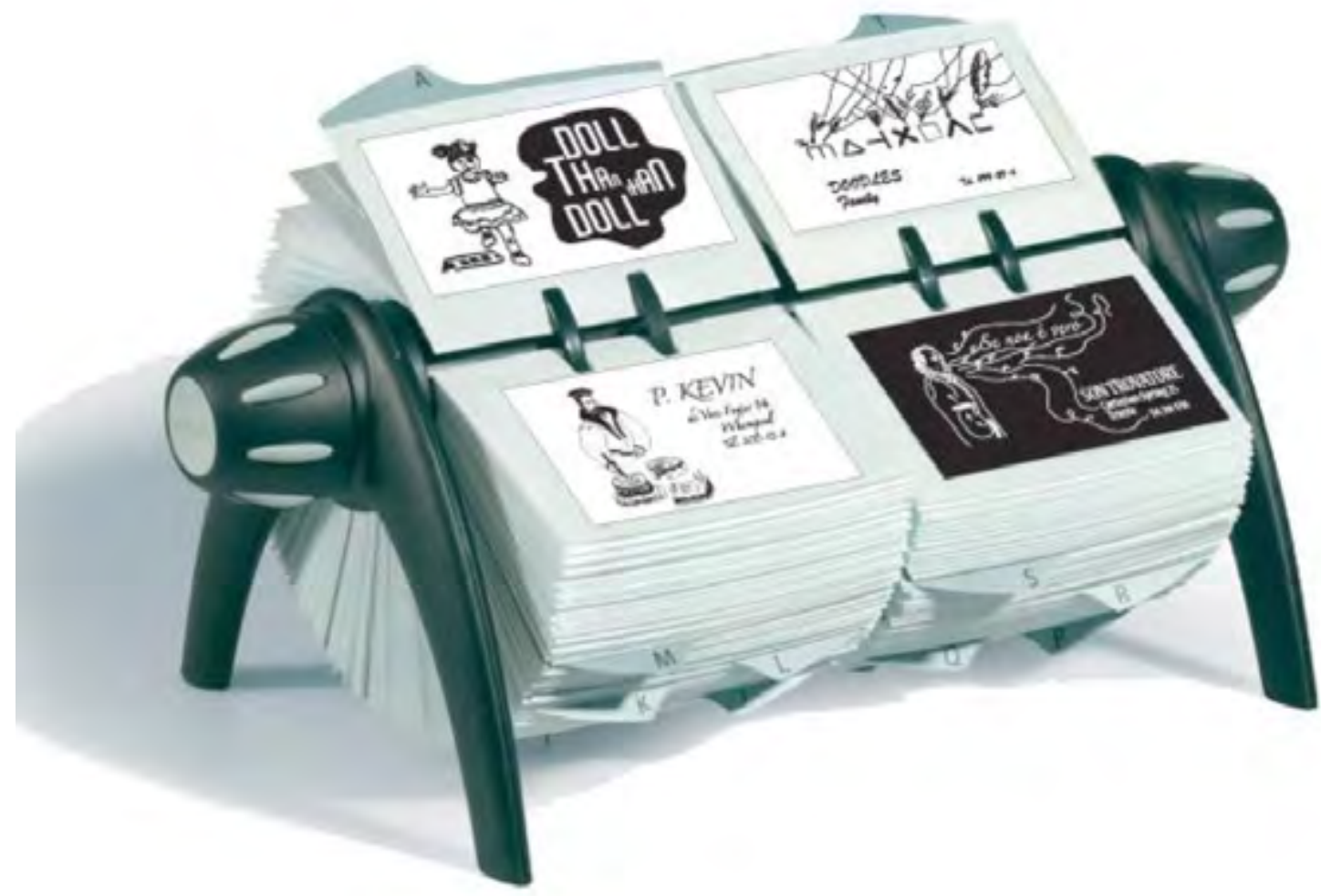

Źródło: culture.pl

Ze względu na niezwykle czasochłonne przygotowanie prototypu na razie istnieje jeden jego egzemplarz, który pokazany został na wystawie zatytułowanej „Krzysztof Bartnicki \& Marcin Szmandra. Finnegans Meet”. Otwarcie odbyło się 5 grudnia 2015 roku w CSW Kronika w Bytomiu, a jej kuratorem był Stanisław Ruksza. Co ciekawe, ten narracyjny dodatek jest zupełnie analogowy, choć przecież nastawiony na recepcję interaktywną i przestrzenną. Slogan towarzyszący wystawie mógłby równie dobrze towarzyszyć typowemu tie-in $\mathrm{w}$ formie gry komputerowej: „Zakręć, by obejrzeć; obejrzyj, by zakręcić (się) i poznać całą rzeszę najdziwniejszych osobników i kuriozów finnegańskiego świata". Dwurzędowy układ przypomi-

${ }^{18}$ M. Sowiński, Conrad Festival: dzień trzeci, „Tygodnik Powszechny”, 21.10.2015, wydanie online, <https://www. tygodnikpowszechny.pl/conrad-festival-dzien-trzeci-30772> [dostęp 1.06.2015].

${ }^{19}$ Por. M. Gliński, Finnegans Wake Rolodexed, „culture.pl”, 8.06.2015, <http://culture.pl/en/article/finneganswake-rolodexed> [dostęp 29.05.2016]. 
na natomiast trochę zabawy OuLiPo spod znaku Sto tysięcy miliardów wierszy, bo obracając dowolnie 'bębny' rolodeksu, odbiorca zaburza pierwotny układ stron, na pierwotnej narracji nabudowując własną.

Badania nad przekładem intersemiotycznym od zawsze stały przed niełatwym zadaniem wypracowania narzędzi opisu, który wykraczałby poza ambiwalencje definicyjne (czy adaptacja jest przekładem intersemiotycznym, jaki jest dopuszczalny stopień dowolności takiego przekładu itp.). Proponuję więc przyjrzeć się potencjałowi narracyjnemu takiego przekładu w kontekście marketingowych strategii transmedialnego storytellingu, w którym za medium uznamy każdą zmianę nośnika - choćby w skali mikro, czyli gatunku tekstu, jeśli ten niesie ze sobą istotne zmiany narracyjne i pozostaje w zależności do oryginału takiej, jak produkty na licencji tie-in względem swoich produktów nadrzędnych. Wówczas przekład ten można wpisać w translatorską serię produktów powiązanych, których funkcją jest opowiedzenie tej samej narracji lub jej spin-offowych derywatów za pomocą innych struktur semantycznych w celu poszerzenia doświadczenia, wzmocnienia potencjału afektywnego, identyfikacji marki czy zwiększenia interaktywności przekazu. A jeśli u podstaw bazowej narracji leży dodatkowo przekład literacki - cóż, wtedy robi się tylko ciekawiej. 


\section{SŁOWA KLUCZOWE:}

o przekładzie inaczej

\section{transmedialny storytelling}

\section{ABSTRAKT:}

Na przykładach literackich, filmowych, muzycznych a także tych wymykających się jednoznacznym gatunkowym klasyfikacjom $\mathrm{w}$ artykule przedstawione zostały translatorskie serie, rozumiane jako ciąg utworów (lub wręcz produktów) interpretujących oryginał (lub siebie nawzajem) za pomocą innych mediów. Tradycyjne ujęcie przywołujące przekład intersemiotyczny w przypadku każdego niejęzykowego przekładu zostało tu jednak wzbogacone o marketingowo-rynkowe motywacje takich translatorskich działań, zwane transmedialnym storytellingiem oraz strategią sprzedaży produktu tie-in. 


\section{przekład intersemiotyczny}

\section{NOTA O AUTORzE:}

Inez Okulska - adiunkt w Polsko-Niemieckim Instytucie Badawczym UAM w Słubicach, teoretyk i krytyk przekładu, autorka opowiadań i felietonów. Odbyła staż podoktorski na Harvardzie. W pracy badawczej zainteresowana socjologicznymi i rynkowymi aspektami przekładu, rolą i funkcją tłumacza, przekładowymi przypadkami granicznymi, tłumaczeniowymi anomaliami. Od niedawna zajmuje się również związkami literatury i nowych mediów oraz szeroko rozumianych technologii. Tłumaczka prozy, poezji i tekstów naukowych, z języków obcych zna również te programowania. 